\title{
Chapter 7 \\ Climate Change in the Attention Arena of the Middle Class
}

\author{
Hans von Storch
}

\begin{abstract}
Good intentions by the middle class are not always well guided and do not always lead to measurable or significant results. For example, efforts to limit greenhouse gas emissions may hold broad appeal but can still have negligible impact. Therefore, it is suggested to embark on "Apollo projects", which bundle the potential and willingness of the middle class. These projects should focus on the development of specific technologies, with economic advantages to support their spread throughout the world. Doing so will harness the middle class in support of greenhouse gas emission reductions in the gigaton-range. Such pan-national projects, for example, could address emission-free ship- or air-propulsion, the electrification of heating or of processes in the chemical industry.
\end{abstract}

\subsection{Introduction}

The middle class needs concerns, real or perceived, as part of life. In the absence of direct threats, such as war, hunger or viruses, then environmental deterioration is a well-received issue by the middle class, and allows for the development and practice of their good intentions.

In the following, first an understanding is introduced: what the "middle class" constitutes. This understanding is clearly a simplification; the middle class is an enormously complex social group, but I hope that some key features are covered well. In particular, I hope that it is clear on the dimension of accepting challenges of somehow "improving the world". Then, I look at the interruption brought by COVID-19 and at the challenge of the more indirect threat and cultural construct of the climate crisis.

The very real problem of anthropogenic climate change, and its anticipated solution as documented in the Paris agreement, is associated with an enormous quantitative challenge: namely the ending of all emissions of greenhouse gases by 2050 , everywhere in the world, and for every purpose. Unfortunately, this is hardly

H. von Storch $(\bowtie)$

Hamburg, Germany 
understood by the middle class. When this quantitative challenge is not understood, the climate crisis cannot be handled. At the end of this article, it is suggested that we build on the goodwill of the middle class to focus our resources on Apollo projects. Such projects are needed to bring about technological advancements that could reduce greenhouse gas emissions in the gigaton-range.

\subsection{The Middle Class and Its Worries}

The term "middle class" goes with a variety of meanings. I will refer to that social stratum where people have a sufficient and secure income, but are not rich. Or, as Wikipedia summaries: "the middle class as having a reasonable amount of discretionary income, so that they do not live from hand-to-mouth as the poor do.... beginning at the point where people have roughly a third of their income left for discretionary spending after paying for basic food and shelter." As such, a significant middle class emerged with the industrialization and with trade, mostly sometime in the nineteenth century.

Thus, I suggest, the members of the middle class do not suffer from significant, immediate and direct problems concerning income, housing and food. While most free resources of the middle class go into increasing income and security, part of their energy is used for developing a good and just lifestyle, and also to protect against dynamics which may threaten their income and security. These threats may be real, but they do not need to be so. In the nineteenth and twentieth centuries the threatening forces were perceived to be the 'underclass' portion of society and their requests for redistribution of wealth and privilege. These days, it could also be seen to be foreigners, perceived as questioning the middle classes' own identity, or superiority rooted in nationalism and racism.

In Europe - I will refer mostly to Northern Europe, which I have observed now for almost 70 years - this middle class became saturated sometime during the 1970s and 1980s. When conventional pressures, such as housing, labour, education and health, became less significant, a new reason of concern emerged, among them the request for a "natural" living milieu. The green motif established itself as a new bourgeois goal, see Radkau (2011).

Initially, attention was paid to the immediate environment (milieu), with a focus on air and water quality, the health of forests and local ecosystems, occupational health and safety, and natural reserves. But it also spread to concerns over radioactivity and nuclear power plants. Later, in the 1990s, the issue of climate change, with its various detrimental effects, became the overarching theme, covering not only the local challenges but also a global existential threat. Nowadays, in the beginning of the 2020s, most environmental concerns are attributed to anthropogenic climate change, although topics such as plastic in the sea or air quality are hardly climate issues.

This conceptualization of the middle class and its embracement of a green agenda represents a massive reduction in complexity. Substantial parts of the middle class are critical of the scientific explanation of anthropogenic climate change, but the 
majority is worried, see NOS (2020). I hope, however, that this reduction in complexity brings forward the significant dimension of the problem at hand, namely, how to effectively deal with the climate crisis.

The concern for climate change is large in the middle class but far from uniform, as an Austrian survey shows. According to this study, better financial status and higher education is associated with a tendency for a deeper concern for climate change ("klimafreundliche Einstellung"), whereas people with forced reduced working hours ("Kurzarbeit") rate climate change less significant, see Resch et al. (2020). This illustrates the duality of relative affluence and climate concerns quite well.

The issue of climate change thus has two dimensions. One is the change itself, whose reality is no longer questioned in science, with its mostly detrimental effects on the geophysical and ecological world. The other dimension constitutes the opportunity for people to build a better world, to use the free energy of the middle class constructively. In Germany, this dimension allows a post-Nazi generation to free itself from the perceived historical guilt of the past crimes against humanity, see Neiman (2019). For the members of the middle class it can be viewed as an active contribution to redeem the sins that the well-off people in the West have committed to the earth's climate.

Anthropogenic climate change is an abstract threat for almost all people. They would not know about it had they not been told about it by the media, by interest groups and scientists. Extreme events are summarily declared to represent this anthropogenic climate change, through every storm, heavy rainfall event and heat wave. At the same time, apocalyptic perspectives of climate change, of future desertification, migration, wars, sea level rise and associated coastal inundation, add to the perception of immediate catastrophe, even if much of these perspectives and interpretations are the result of exaggerations. Even so, they serve the purpose of creating concern and the providing the option of "saving the world".

\subsection{Sentiment Can Reverse Quickly - The Virus}

But then, suddenly, the virus came and brought back immediate and direct threats. People became ill, some died. It seems that in terms of the number of infected and diseased people, the present pandemic compares, at least for New York, to the pandemic of the Spanish flu of 1918-20, see Mandavilli (2020).

Not surprisingly, the issue of the virus gains very high attention in surveys about public concern. The levels of immediate concern for both the virus and the climate became comparable. A German newspaper, Der Spiegel, reported that a survey taken in the spring of 2020 in Germany showed younger people (28-45 years old) to rate climate change as the dominant challenge (50\%), whereas a majority of 53\% of those older than 45 years pointed to the pandemic, see Wahnbaeck (2020).

Indirect evidence of this abrupt change of attention away from climate to the pandemic, is illustrated in Fig. 7.1, which shows a substantial increase of the presence of "climate" in the monitored media from 2017 to 2019; with substantial 


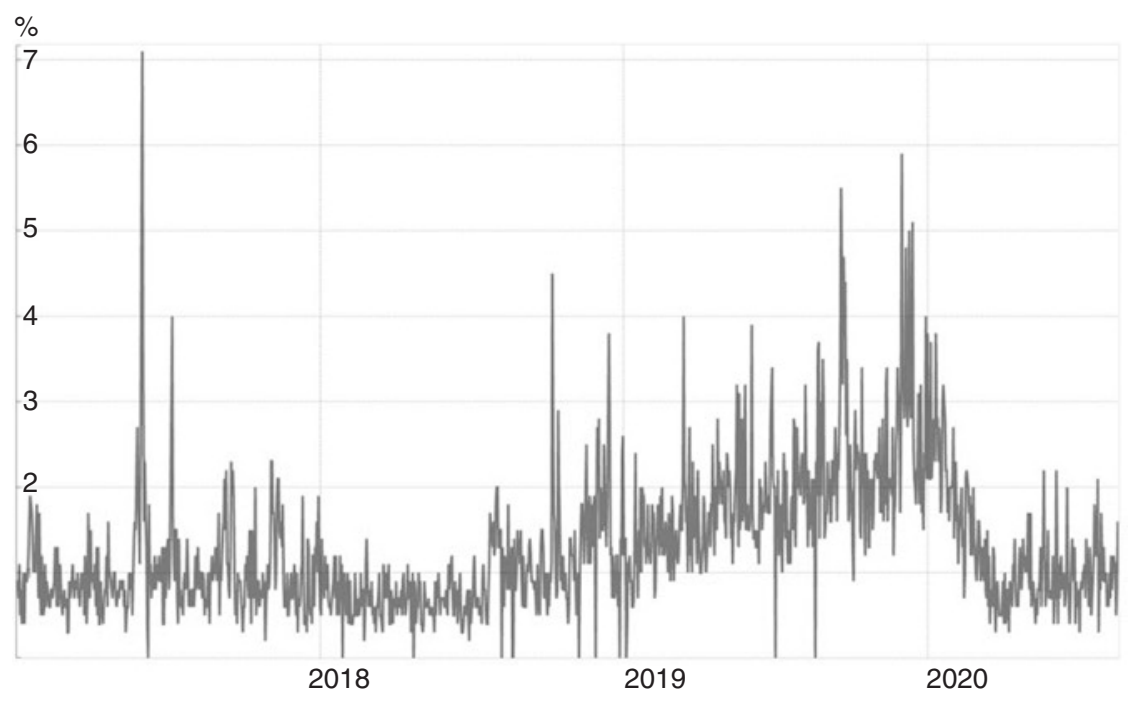

Fig. 7.1 Percentage of climate change related articles online in Europe. (Source: The online media monitor on Climate Change (OMM), Bruggemann and Sadikni (2020))

decrease from January 2020, and settling back to values similar to those before 2018 from April 2020.

These tendencies illustrate that the trend towards deeper environmental concern, associated with growing affluence in the middle class, is not irreversible. Abrupt changes of attention happen, when another issue unexpectedly emerges that is perceived as significant. An example of this would be the attack in 2001 on the TwinTowers in New York, which immediately lifted the concern about terrorism to top levels. Similarly, in the summer of 2015, the massive influx of refugees into the EU caused a short-term re-orientation of public attention.

\subsection{Climate Change Concerns as a Cultural Phenomenon}

The concern that human failures (our "sins"), would cause adverse climatic conditions is as old as civilization, it seems, see von Storch and Stehr (2000). In premodern times, religious explanations for deficits of precipitation, or for disastrous summers leading to failing harvests were the standard method to make sense of the world, see, e.g., Kershaw (1973). Through nature, God retaliates for the "sins" of humans. This traditional thinking is still used today. For example, some people attributed the flooding of New Orleans to God's judgement over the abortion-clinics in that city. Likewise, The Guardian (2014) reported how some people blamed the 2014-flooding in the UK to the acquiescence to same-sex marriages. In modern 
times, the same revenge/punishment mechanism is often claimed to be at work, although "God" may be replaced by "Nature".

This idea of retaliation is a Western pattern of thinking, and research on these topics from those in other cultures would be interesting to have. However, given the dominance of post-colonial Western thinking, the Western ideas may also prevail in other parts of the world, even if possibly in a weaker form. In an analysis of coastal flooding in Ghana, such flooding was mostly understood as an "act of God", but without the interpretation of it being sent as a punishment, see Evadzi et al. (2018).

The concept of climate change as a response to human misdoings, is age-old and seems to be an integral part of our culture. Because of this, it can be resurface at any time, with silent public acceptance. A sample of related conversations may therefore sound like this: "We knew it all along, but it is good that science is now confirming it."

\subsection{Challenges for Obtaining Efficient Interventions}

The public, and especially the middle class, is keen on acting against the detrimental scenarios of catastrophic climate change becoming real. While industry, traffic and lifestyles of others are considered the main culprits for the pending disaster, people also want to contribute to the solution by individual action. This wish manifests itself in a large variety of activities, of which many serve other purposes, such as animal health, undisturbed neighbourhoods, air quality, noise disturbances near airports, etcetera. These are often presented as measures to help combat the climate problem, because they could lead to "large" reductions of emissions. However, even though these reductions may appear large when presented in terms of tons of emissions impact, in reality, they are virtually irrelevant on a global scale. This becomes especially clear when measuring the amount of $\mathrm{CO}_{2}$ emitted on a global basis, namely about 38 billion tons (Gigatons $=\mathrm{Gt}$ ) of $\mathrm{CO} 2$ per year. This is the true target for emissions reduction, all of which must come to an end by 2050 in order to meet the goals of the Paris agreement, see IPCC (2014).

An example of these good-sounding but insignificant initiatives was the claim, published in the Danish middle-class journal Politiken (2020), that sorting wastetextiles would contribute ("help") to limit climate change. While this sorting of waste-textiles may make sense for various reasons, there is hardly any measurable effect on climate-relevant emissions. The actions may contribute to a more sustainable economy, but it would not aid in the combat of climate change in any significant way. Not surprisingly, the article only claims that it would "help", and does not quantify it any further.

Obviously, it is difficult for the public to understand the sheer size of the challenge. Most people seem to believe that their actions would matter, hoping that others would follow their good example, which is then assumed to become effective as the sum of all the individual actions. Simple calculations, however, often show that this still does not lead to reductions in the gigaton-range. 
The IPCC summarizes the conditions for reaching the Paris goal, of limiting the increase of global mean temperature to $1.5^{\circ} \mathrm{C}$ until the end of the century, with stationary conditions ${ }^{1}$ afterwards. This goal requires that today's emission of anthropogenic $\mathrm{CO}_{2}$ of about $38 \mathrm{Gt} \mathrm{CO}$ /year (and other greenhouse gases) is reduced so that the net-emission in 2050 has completely ceased. This has to happen on a planetary scale, everywhere in the world, from all human activities, with subsequent negative emissions in the range of several $\mathrm{Gt} \mathrm{CO}_{2}$ /year in the decades to follow.

This simple quantitative assertion is generally not understood by the public, nor by well-meaning, concerned civil society, such as the Fridays for Future movement. They are seriously worried about or even scared of the perspective of future manmade climate "catastrophes". The task is daunting, but instead of asking "how can this be achieved', populistic requests are aired, to reach these goals of net-zero emissions much earlier, say for Hamburg in 2035. For me, it seems that such groups are not necessarily battling anthropogenic climate change, but use its goals as a vehicle to persuade society to achieve other middle-class goals, in particular to a healthier and supposedly happier life of its members.

The fact that achieving the goal of net-zero emissions requires all societies in the world to adopt it has already been formally accepted by almost all governments of the world. Even so, present efforts do not indicate that we will achieve this goal. ${ }^{2}$ This is not really surprising, because the societies and countries of the world face with a variety of challenges, of which climate change is just one. Competition for attention and investment include the previously-mentioned existential worries about food, housing, labour, education and health - commensurate with the fact that many in the world have not yet made it to middle class. The traditional social-democratic issues only lose significance for those who made it into middle class: no poverty, zero hunger, good health and well-being, with a high quality of education, as the United Nations (2015) puts it.

I believe that unorganized citizen activity will not lead to success, not even partial success. We, and the question is of course who "we" are, need to do something else to limit the detrimental climatic effects of ongoing emissions of greenhouse gases into the atmosphere, without neglecting or belittling existing UN development goals for basic well-being and development. For this, we have a tool: the goodwill and intention of the Western middle-class. This tool therefore needs to be focused on the most effective measures, which will likely include other development goals as well.

\footnotetext{
1 "Stationary conditions" = the temperature varies around this value with relatively small deviations, but there is no systematic in- or decrease.

${ }^{2}$ According to https://climateactiontracker.org/countries/, only two countries are presently underway to meet their Paris obligations: Morocco and Gambia. The EU is classified as "insufficient". [As of 26. August 2020.]
} 


\subsection{Focusing the Goodwill of the Western Middle-Class: Apollo Projects}

On 12 September 1962, John F Kennedy announced his Apollo project: "We choose to go to the Moon in this decade ..., not because [it is] easy, but because [it is] hard; because that goal will serve to organize and measure the best of our energies and skills, because that challenge is one that we are willing to accept, one we are unwilling to postpone, and one we intend to win....". He suggested to bundle the potential and the will of the United States and its people to do something difficult to achieve. And he added a date: within 10 years. A challenging problem-oriented technological feat, a specific timing and an opportunity for all Americans to be proud of.

Can we think of developing such problem-oriented technologies within a specific time frame, which would allow the middle class take ownership of and be proud in? I would say, 'Yes, we can.' We could suggest that, based on technological expertise, over the next 10 years, Germany could work to develop emission-free ship propulsion; France could do the same with regards to air traffic; and China could work on the electrification of chemical process heat. For further example, Russia could work on the electrification of heating and cooling; and Tanzania could work on providing renewable energy for rural African regions. ${ }^{3}$ All of this could be done without compromising the basic development goals of eliminating hunger and poverty, provisioning health and education.

By starting such projects, with the positive attitude of "we can do this" and "we will do it", a constructive combination of the moral inclinations of families, companies and governments for an efficient "stewardship of the natural environment and the climate" may be achieved.

Clearly, even without new middle-class driven and financed Apollo-projects, efforts towards emissions-free technologies are underway in various quarters of science and companies. Governments make big investments into such efforts - but it seems the success is slow. Taking the suggested "Apollo-projects" approach will help bring about both the needed acceleration and scale to the initiatives already on the table to reduce greenhouse gas emissions.

The new Apollo-challenge can be financed by the middle class who eagerly wants to contribute to solving the climate problem, but does not know exactly how to assist or engage. Until now, the middle classes of various countries are spreading goodwill and money for various symbolic acts with no or little gigaton-range effect. The Apollo-challenge targets are visions that can will convince the rest of the world that we are serious. Not by self-acclaimed moral superiority but by economic power, so that everywhere in the world large chunks of emissions of greenhouse gases are phased out - with net-effects in the gigaton-range.

For the sake of clarity, a brief account of the challenge of heating and cooling may be useful. In the EU, the total annual amount of emissions related to heating and cooling is about 1 gigaton of $\mathrm{CO}_{2}$ /year. If sufficient electrical energy is

\footnotetext{
${ }^{3}$ Much better attributions may be possible; this list a mere illustration of what is meant.
} 
available, this process could be transformed to run on electricity without emissions. For this transformation, the energy supply must be safe and reliable. However, there are also practical considerations, such as allowing large housing companies (such as SAGA in Hamburg) the ongoing utilization of older and often culturally valuable buildings and locations. Regardless of the opportunities or challenges, for technologies such as these to spread around the world, they need to first and foremost be economically attractive. Only then can the smaller achievements of avoiding several megatons of emissions on a local basis may become an efficient emission reduction in the multi-gigaton range on a global scale.

\subsection{Conclusion}

In this chapter I have suggested that the goodwill of the middle class in the area climate change is often misguided towards symbolic acts that do not contribute to the real problem of reducing emissions efficiently. Moreover, the attention span of the public might not be long enough that would be needed for a sustained focus on small-scale improvements.

Therefore, I suggest national - or pan-national - projects, for development of technologies that are, first: economically attractive, to be accepted everywhere in the world, and second: effective in making emissions obsolete in sectors which today cause large amounts of emissions, such as traffic, heating and cooling, agriculture and industry. These projects could be financed by tax on the affluent, thereby giving the middle class the feeling that it is taking responsibility and the pride for the great task of making the world a better place.

Another great American declared "I have a dream", and surely, the national and pan-national cooperative Apollo-challenges of today are a dream. We need politicians who are able to balance the various interests, cultural frames and short-term economic boundaries. We also need to organize the difficult social and political processes. We need enthusiastic and competent engineers. And, most of all, we need the middle class with its willingness to engage for a common good.

\section{References}

Brüggemann, M., \& Sadikni, R. (2020). Online media monitor on climate change (OMM): Analysis of global tweets and online media coverage. Universität Hamburg. https://icdc.cen. uni-hamburg.de/omm/world.html. Accessed 6 May 2021

Evadzi, P., Scheffran, J., Zorita, E., \& Hünicke, B. (2018). Awareness of sea-level response under climate change on the coast of Ghana. Journal of Coastal Conservation, 22(1), 183-197.

IPCC. (2014). Climate change 2014. Synthesis report summary for policymakers. UN Intergovernmental Panel on Climate Change. https://www.ipcc.ch/site/assets/uploads/2018/02/ AR5_SYR_FINAL_SPM.pdf 
Kershaw, I. (1973). The great famine and agrarian crisis in England 1315-1322. Past \& Present, 59, 3-50.

Mandavilli, A. (2020). In N.Y.C.'s Spring Virus Surge, a Frightening Echo of 1918 Flu, New York Times, 13 August 2020. https://www.nytimes.com/2020/08/13/health/coronavirus-flu-newyork.html. Accessed 15 Aug 2020.

Neiman, S. (2019). Learning from the Germans. Confronting race and the memory of Evil. Farrar Straus \& Giroux.

NOS. (2020). Ruime meerderheid van Nederlanders denkt dat het klimaat verandert, 17 January 2020. https://nos.nl/artikel/2319094-ruime-meerderheid-van-nederlanders-denkt-dat-hetklimaat-verandert.html

Politiken. (2020). Tøjsortering kan hjælpe klimaet, Politiken, 16 August 2020, p. 14.

Radkau, J. (2011). Die Ära der Ökologie. Eine Weltgeschichte. CH Beck.

Resch, T., Waibel, M., \& Kittel, B. (2020). Corona, Umwelt, Klima \& Nachhaltigkeit, 3 July 2020. https://viecer.univie.ac.at/corona-blog/corona-blog-beitraege/blog63/. Accessed on 15 Aug 2020.

The Guardian. (2014).UK storms are divine retribution for gay marriage laws, says UKIP councilor, 18. January 2014.

United Nations. (2015). The social development goals. Obtained from https://sdgs.un.org/goals, as of 20 August 2020.

von Storch, H., \& Stehr, N. (2000). Climate change in perspective. Our concerns about global warming have an age-old resonance. Nature, 405, 615.

Wahnbaeck, C. (2020). Junge fürchten den Klimawandel mehr als das Virus, Der Spiegel, 17.04.2020. https://www.spiegel.de/wirtschaft/leben-mit-corona-umfrage-junge-fuerchtenklimawandel-mehr-als-corona-a-21f6a7f4-8f7e-479f-8c0a-d0c547c3e4ed

Hans von Storch is a German climate scientist and lead author of the 3rd and 5th assessmentreport of the IPCC, the UN's climate panel. He is a Professor at the University of Hamburg, and was until 2016 Director of the Institute for Coastal Research at the Helmholtz Helmholtz Zentrum Geesthacht (now Helmholtz Zentrum Hereon, earlier: GKSS Research Center) in Geesthacht, Germany. He is a member of the advisory boards of, among others, the Journal of Climate and editor-in-chief of Oxford University Press Research Encyclopedia Climate Science. He holds a honorary doctorate of the University of Gothenburg, and is a foreign member of the Polish Academy of Sciences, as well as a guest professor at the Ocean University of China. He is a recipient of the order of the Federal Republic of Germany.

Several joined in a critical assessment of the manuscript, thanks to PT, JF, EZ, AWH, RG, AS, HV and RH. The chapter was completed on 1. September 2020; minor clarifications were added in November 2020.

Open Access This chapter is licensed under the terms of the Creative Commons Attribution 4.0 International License (http://creativecommons.org/licenses/by/4.0/), which permits use, sharing, adaptation, distribution and reproduction in any medium or format, as long as you give appropriate credit to the original author(s) and the source, provide a link to the Creative Commons license and indicate if changes were made.

The images or other third party material in this chapter are included in the chapter's Creative Commons license, unless indicated otherwise in a credit line to the material. If material is not included in the chapter's Creative Commons license and your intended use is not permitted by statutory regulation or exceeds the permitted use, you will need to obtain permission directly from the copyright holder.

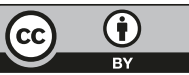

